\title{
Computer-aided Analysis of Selective Phytochemicals as Potent Inhibitors of Parkin: Major Biological Target of Parkinson's disease
}

\section{Nadia Arif' ${ }^{1}$, Andleeb Subhani' ${ }^{1}$, Waqar Hussain ${ }^{2,3}$ and Nouman Rasool ${ }^{3 *}$}

'Department of Life Sciences, University of Management and Technology, Lahore-54770, Pakistan

${ }^{2}$ National Center of Artificial Intelligence, Punjab University College of Information Technology, University of the Punjab, Lahore-54000, Pakistan

${ }^{3}$ Center for Professional Studies, Lahore-54000, Pakistan

\section{Received: 02 February, 2020 \\ Accepted: 09 June, 2020 \\ Published: 10 June, 2020}

*Corresponding author: Nouman Rasool, Center for Professional Studies, Lahore-54000, Pakistan, E-mail: noumanrasool@gmail.com

Keywords: ADMET; Band energy gaps; Parkin; DFT; Molecular docking; Phytochemicals

https://www.peertechz.com

Check for updates

\section{Abstract}

Parkinson's disease, caused by mutations in the Parkin that leads to loss of neuron is the second most widespread neurodegenerative disorder in the world. Phytochemicals are being considered due to their medicinal properties to cure many human diseases. The present study targets the inhibition of Parkin, a major biological target for Parkinson using 3150 phytochemicals from various medicinal plants. These plants are naturally growing in a local climate of Pakistan, India and China and being used for a long time for the medicinal purpose. A total of 3150 phytochemicals from various medicinal plants were collected for this in silico study. The pharmacological assessments prediction, molecular docking and density functional theory (DFT) based studies were done to find out the latent inhibitory properties of these phytochemicals against Parkin. Out of 3150 phytochemicals, 175 showed human-suitable pharmacological properties and among those 175 compounds, 5 phytochemicals, i.e. Liquirtin, Shinflavanone, Glabrone, GlycyrdioneB and IsoangustoneA to have potent inhibitory properties against Parkin and can be deliberated for additional in vitro and in vivo studies to evaluate their inhibitory effects against Parkin. They revealed binding affinity greater than various previously reported inhibitors against Parkin. Additionally, DFT based analysis exhibited high reactivity for these five phytochemicals in the binding pocket of Parkin, based on $\mathrm{E}_{\mathrm{uo}^{\prime}} \mathrm{E}_{\mathrm{Hom}}$ and band energy gap. A total of 5 out of 175 phytochemicals are reported as highly potent inhibitors against Parkin which are liquirtin, Shinflavanone, Glabrone, Glycyrdione B and IsoangustoneA from the same medicinal plant Glycyrrhiza glabra. However, these 5 phytochemicals can be considered for further in vivo and in vitro analysis for the clinical development of a drug against the world's second most common brain disorder, the Parkinson's disease.

\section{Graphical abstract}

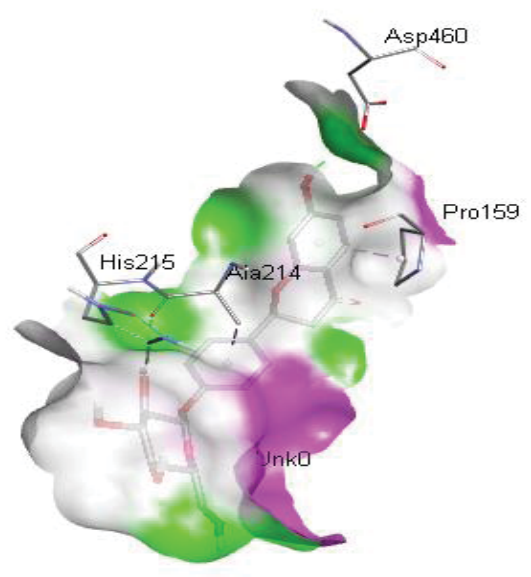




\section{Introduction}

Parkinson's disease (PD) is the second most common and prevalent neurodegenerative disorder. It is characterized by loss of dopaminergic neuron in the Substantia Nigra Pars Compacta (SNpc), the formation of Lewy bodies (LBs) and progressive deterioration of motor function. Several genes are known to be associated with the familial forms of PD [1], while Parkin mutations are the key source of early-onset PD [2]. It is categorized by two types of syndromes; motor symptoms and non-motor symptoms. The former type includes bradykinesia, hypokinesia, inflexibility, quiescent tremor, and postural unpredictability. Later type includes autonomic dysfunction, sleep irregularities, depression, anxiety and loss of memory (dementia) [3- 5]. Dementia is a major cause of debility, and presently there is no effective indicative treatment of PD like the Alzheimer's disease (AD) and 47\% of PD patients show sign of depression [6].

Structurally, Parkin comprises of an N-terminal ubiquitinlike (Ubl) domain, a linker region, RINGo domain, a RING1 domain, a RING (IBR) domain and a RING2 domain at the C terminus. Functionally Parkin acts as an E3 ubiquitin ligase [7], and its E3 ligase activity can be positively controlled through neddylation and sulfhydration or by regulators, such as CHIP, HSel-10, SUMO-1, and PINK1 [8-10].

Since PD is described clinically by intracellular protein aggregates termed Lewy bodies, it is postulated that Parkin is used for promoting the UPS, which is activated by $\mathrm{K} 48$ linked polyubiquitination of substrate proteins [11]. Mutation of Parkin damages the ubiquitin-proteasome pathway (UPS) of protein degradation and leads to the lethal accumulation of misfolded or aggregated proteins, Subsequently, the discovery that Parkin promotes mitophagy [12] has been proved through experiments that the ubiquitination of mitochondrial proteins by Parkin triggers the autophagic machinery through staffing of ubiquitin-binding adaptors, such as HDAC6 and p62/ SQSTM1. This is the actual mechanism that how Parkin involves in Parkinson's diseases [13-15]

Previous studies demonstrate that selective mutations in the Parkin have been reported in sporadic Parkinson's disease [16-18]. Thus, it would be interesting to discover potential inhibitors that inhibit the mechanism Parkin gene and that will surely provide a new perspective for the treatment of Parkinson's disease as many loss-of-function mutations in Parkin have been linked with hereditary PD $[19,20]$.

Phytomedicines are generally planted derivative medicines formed by compounds termed as phytochemicals. These are naturally occurring compounds having copious medicinal properties. The effectiveness of phytochemicals against various chronic diseases has been reported in many studies [21]. The phytochemicals are produced during biosynthetic pathways of the plants and acts as secondary metabolites, and there is an enormous diversity of these compounds which are known to have potential antiviral, antibacterial, antifungal, anticancer, and other properties [22]. The phytochemicals found in different groups like alkaloids, flavonoids, terpenoids and sesquiterpenes and each group of these disease-preventing phytochemicals consists of a number of different chemicals with different potential [23].

The in silico methodologies using computational approaches facilitate the drug discovery process since the screening of drugs using in vitro and in vivo analysis is becoming increasingly challenging, time-consuming and expensive due to a high number of compounds under investigation. Thus, computational techniques are making the analysis economical and resource efficiency. Within the same time, far more drugs can be discovered using the computational biology and chemistry mechanisms with the least investment of money and time. Remunerations of using in silico methods can be subjugated the whole process of drug development, i.e. from the preclinical discovery phase to the late phase of clinical development. In silico drug discovery methods helps to evaluate the potent and most important medicinal compound with high efficiency [24].

Herein, we target the inactivation of Parkin, leading cause of Parkinson's disease, with phytochemicals derived from different medicinal plants locally found in Pakistan, India and China. Majorly, these plants included Glycyrrhiza glabra (mulathi), Huperzia serrata (toothed clubmoss), Magnolia officinalis (Magnolia bark), Uncaria rhynchophylla (cat's claw herb), Valeriana officinalis (Balchar), Acorus calamus (Sweet flag) and Curcuma longa (Turmeric) etc. The phytochemicals from these above-mentioned plants are known to have an inhibitory effect against many viral and bacterial diseases [25]; though, this study evaluated the inhibition potential of these phytochemicals against Parkin

\section{Methodology}

Structure retrieval

This study targeted the discovery of potential inhibitors against Parkin, crystal structure of the protein was required. Structure of the targeted protein was available at RCSB PDB [26] and was downloaded in PDB format using PDB ID: 5C1Z.

\section{Collection of phytochemicals}

A total of 3150 phytochemicals were collected from different plants. Firstly, the plants were searched out using different keywords, and then their phytochemicals were searched out using a literature survey. It took a few months to select and to find out their structures. After searching plants and their phytochemicals, 3D structures of all the phytochemicals were downloaded from PubChem and DrugBank.

\section{ADMET Analysis and drug-likeness prediction}

By using the PreADMET server [27], phytochemicals were screened out on the basis of following pharmaceutical properties which were solubility (ESOL), gastrointestinal (GI) absorption, blood-brain barrier (BBB) Permeability, Lipinski's rules violations, toxicity and carcinogenicity.

In this study the criteria set for initial screening was; 
- Lipinski's violations must be 0 ,

- Solubility should be high or moderate,

- $\quad$ GI absorption must be high,

- $\quad$ BBB-permeability should be positive,

- $\quad$ Carcinogenicity and Toxicity = Zero/Nil [28].

Molecular docking and binding energy calculations

Molecular docking of Parkin with screened phytochemicals was accomplished using AutoDock Tools and AutoDock Vina $[29,30]$. AutoDock Tools were used to prepare Parkin by the addition of polar hydrogen bonds and removal of nonstandard residues which improved the interactions between phytochemicals and Parkin. A three-dimensional grid for Parkin was designed with a size of $16 \times 14 \times 18 \AA^{3}$, to explicate the search space for phytochemicals to be docked against Parkin. To calculate the binding affinities of different phytochemicals with our target protein, AutoDock Vina [31] was run through command prompt to get binding affinities ( $\mathrm{kcal} / \mathrm{mol}) . \mathrm{K}_{\mathrm{i}}$ values of the compounds were estimated by using this formula:

$$
\mathrm{Ki}=\mathrm{e}^{\Delta \mathrm{G} / \mathrm{RT}}(\mu \mathrm{M})
$$

After calculating binding affinities, complexes of protein and phytochemicals were formed using Chimera 1.11.2rc. Discovery Studio 2.5 was used to get interaction plots.

\section{Density functional theory analysis}

To analyze the reactivity and efficiency of the strongly docked phytochemicals against Parkin, a density functional theory (DFT)-based analysis was performed using highest occupied molecular orbital (HOMO) and lowest unoccupied molecular orbital (LUMO) energy by relating the Becke, 3-parameter, Lee-Yang-Parr (B3LYP) correlation function of DFT [32]. The band energy gap $(\Delta E)$ was also measured using the expression $\mathrm{E}_{\mathrm{Luмо}}-\mathrm{E}_{\text {номо }}$. The energy estimations were made using ORCA Program [33].

\section{Results}

\section{Pharmacological assessment of phytochemicals}

Before docking, Absorption, Distribution, Metabolism, Excretion and Toxicity (ADMET) profiles of all the phytochemicals were analyzed; to either they are drug-like or not. After evaluation of all the 3150 phytochemicals, 175 proved as being BBB permeant, high GI absorption, o Violations of Lipinski's Rule, Optimum EOSL solubility, non-carcinogenic and non-toxic. Previously reported (in literature) inhibitors of Parkin were also searched and the results of phytochemicals were compared. Total 15 compounds were found and their screening was done. ADMET results of these 15 compounds showed that they all are not optimally suitable for human administration (Table 1).

\section{Molecular docking of phytochemicals with Parkin}

Molecular docking of the selected 175 phytochemicals (after ADMET analysis) was performed to calculate their binding energies and Ki values against Parkin. For comparison, the previously reported inhibitors were also docked. These inhibitors showed maximum binding affinity of $-5.2 \mathrm{kcal} / \mathrm{mol}$ (Table 2). These compounds were Carbonyl cyanide 3-chlorophenylhydrazone, Coenzyme Q10, Creatine, Epoxomicin, Isradipine, Levodopa, Mavoglurant, MG132, MitoPBN, MitoQ NAM, Niacin, SS-20, SS-31 and VitaminK2. Out of these 15 compounds, Mavoglurant showed highest binding affinity $-5.2 \mathrm{kcal} / \mathrm{mol}$ and $\mathrm{K}_{\mathrm{i}}=152.807 \mu \mathrm{M}$ while making interactions with $\mathrm{Arg}_{156}, \mathrm{Pro}_{153,}, \mathrm{Cys}_{154}, \mathrm{Pro}_{159}, \mathrm{His}_{215}, \mathrm{Ala}_{214}$ residues of Parkin protein. While niacin showed the lowest affinity amongst all which is $-3.3 \mathrm{kcal} / \mathrm{mol}\left(\mathrm{K}_{\mathrm{i}}=4485.181 \mu \mathrm{M}\right)$ and docked at $\mathrm{Cys}_{154}, \operatorname{Pro}_{153}, \mathrm{Arg}_{156}, \mathrm{Gln}_{158}, \mathrm{Ala}_{214}, \mathrm{His}_{215}$ residues of the targeted protein (Table 2).

Table 1: ADMET results of previously reported (in literature) inhibitors.

\begin{tabular}{|c|c|c|c|c|c|c|}
\hline Inhibitor & ESOL Class & GI absorption & BBB permeant & Lipinski \#violations & Carcinogenicity & Toxicity \\
\hline $\mathrm{CCCP}$ & Soluble & High & Yes & 0 & No & No \\
\hline CoQ10 & Poorly soluble & High & No & 2 & No & No \\
\hline Creatine & Very soluble & Low & No & 1 & No & No \\
\hline Epoxomicin & Moderately soluble & High & Yes & 0 & No & No \\
\hline Isradipine & Very soluble & High & No & 0 & No & No \\
\hline Levodopa & Soluble & High & No & 0 & No & No \\
\hline Mavoglurant & Moderately soluble & High & Yes & 1 & No & No \\
\hline MG132 & Poorly soluble & High & No & 2 & No & No \\
\hline MitoPBN & Moderately soluble & High & No & 0 & No & No \\
\hline MitoQ & Soluble & High & Yes & 0 & No & No \\
\hline NAM & Highly soluble & High & No & 0 & No & No \\
\hline Niacin & Moderately soluble & High & No & 0 & No & No \\
\hline SS20 & Very soluble & High & No & 0 & No & No \\
\hline SS31 & Highly soluble & High & No & 0 & No & No \\
\hline VitaminK2 & Soluble & High & Yes & 0 & No & No \\
\hline
\end{tabular}

Citation: Arif N, Subhani A, Hussain W, Rasool N (2020) RComputer-aided Analysis of Selective Phytochemicals as Potent Inhibitors of Parkin: Major Biological Target of 


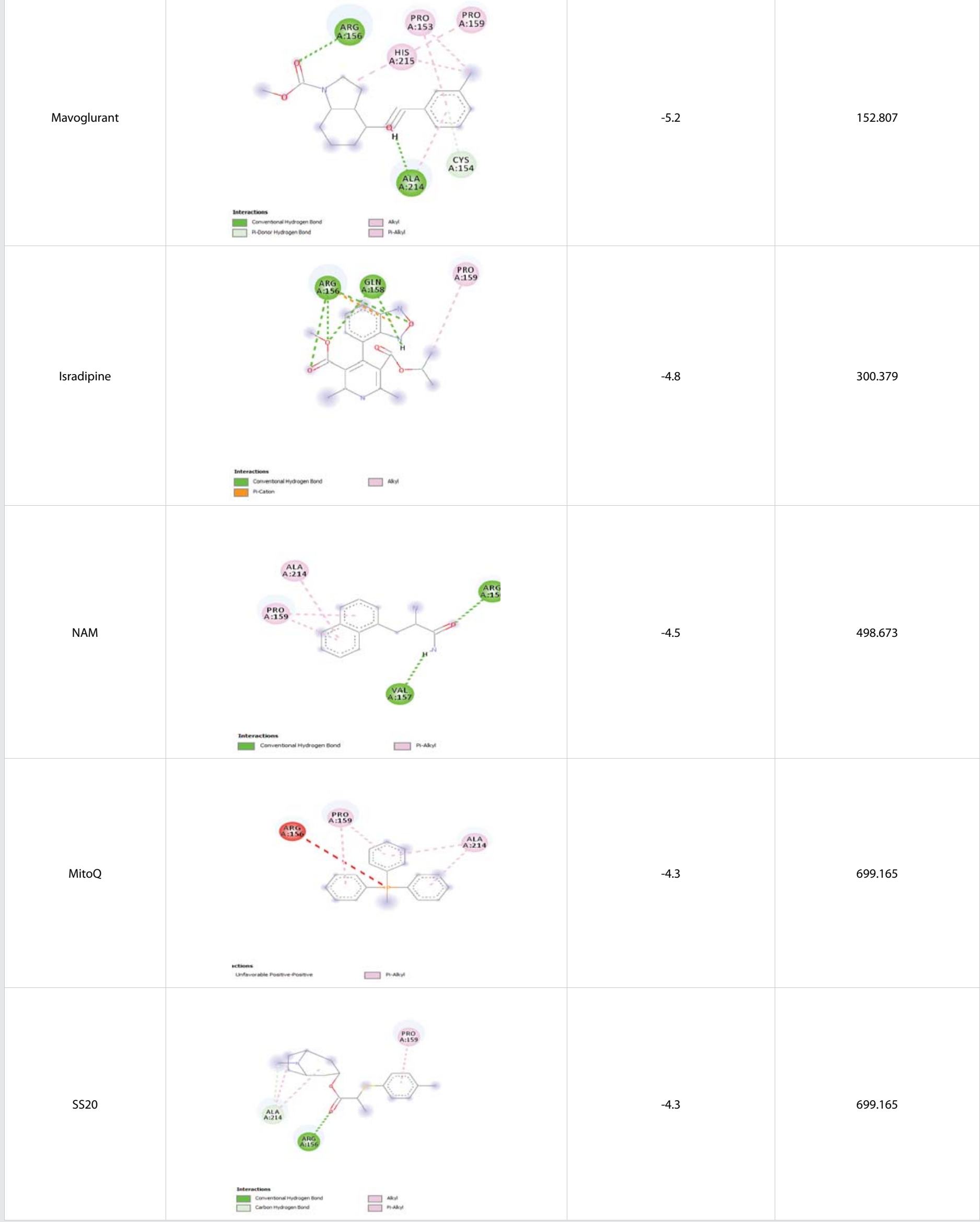

Citation: Arif N, Subhani A, Hussain W, Rasool N (2020) RComputer-aided Analysis of Selective Phytochemicals as Potent Inhibitors of Parkin: Major Biological Target of Parkinson's disease. Glob J Biotechnol Biomater Sci 6(1): 013-023. DOl: https://dx.doi.org/10.17352/gjbbs.000013 


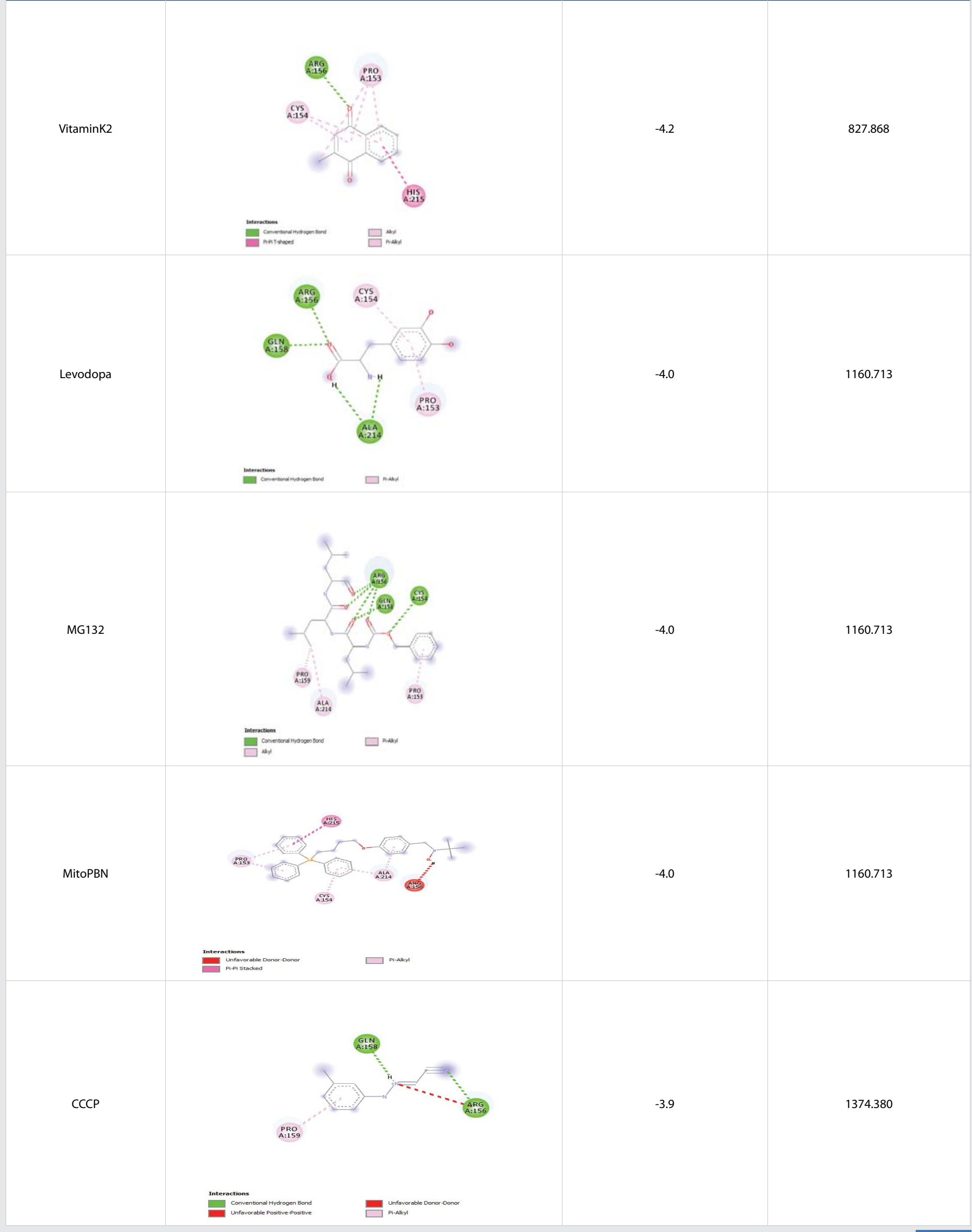

Citation: Arif N, Subhani A, Hussain W, Rasool N (2020) RComputer-aided Analysis of Selective Phytochemicals as Potent Inhibitors of Parkin: Major Biological Target of Parkinson's disease. Glob J Biotechnol Biomater Sci 6(1): 013-023. DOl: https://dx.doi.org/10.17352/gjbbs.000013 


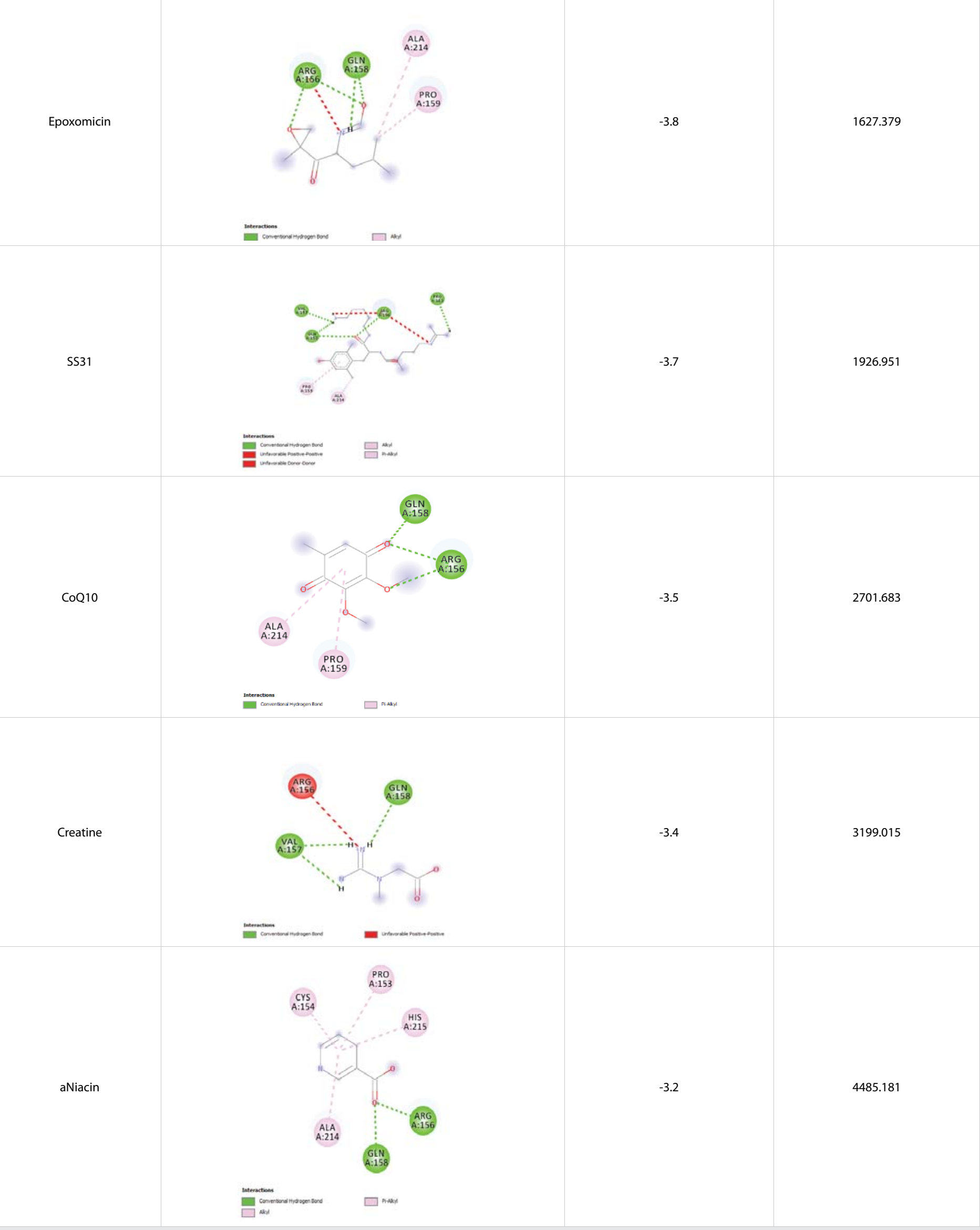


The 175 docked phytochemicals from different plants behave differently while making interactions with the protein. Out of these, five phytochemicals showed highest binding affinities i.e. greater than $-5.2 \mathrm{kcal} / \mathrm{mol}$ (maximum of previously reported inhibitors) which were Liquirtin, Shinflavanone, Glabrone, GlycyrdioneB and IsoangustoneA from the plant Glycyrrhiza glabra (Table 3).These five phytochemicals were from the same plant but had different binding affinities and Ki values. Liquirtin and Shinflavanone have shown having $-5.5 \mathrm{kcal} / \mathrm{mol}$ binding affinity $(\mathrm{Ki}=92.044 \mu \mathrm{M})$, made interaction with His $_{215}$, Ala $_{214}$, Pro $_{159}, \mathrm{Asp}_{460}$ and Pro $_{159}, \mathrm{Ala}_{214}, \mathrm{Arg}_{156}, \mathrm{Cys}_{154}, \mathrm{His}_{215}, \mathrm{Pro}_{153}$ residues of Parkin protein respectively (Table 3). Glabrone

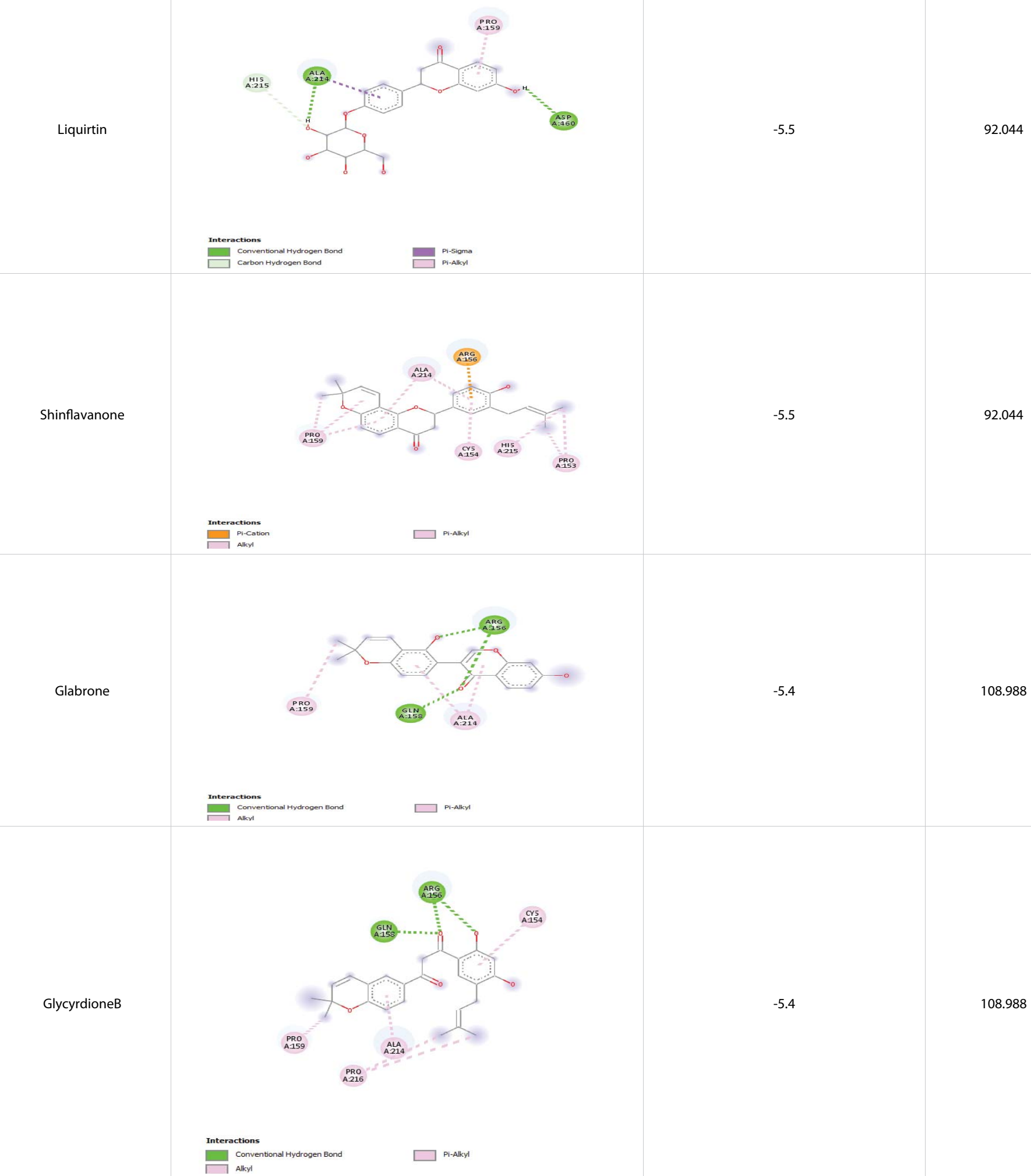




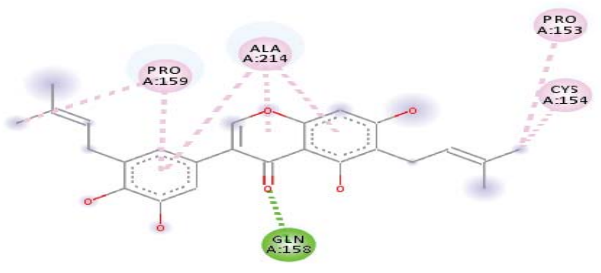

and GlycyrdioneB interacted with $\operatorname{Pro}_{159}, \mathrm{Gln}_{158}, \mathrm{Arg}_{156}, \mathrm{Ala}_{214}$ and $\mathrm{Pro}_{15}, \mathrm{Pro}_{216}, \mathrm{Ala}_{214}, \mathrm{Gln}_{158}, \mathrm{Arg}_{156}, \mathrm{Cys}_{154}$ residues respectively , having binding affinities of $-5.4 \mathrm{kcal} / \mathrm{mol}(\mathrm{Ki}=108.988 \mu \mathrm{M})$. IsoangustoneA from the plant, G. glabra docked at $\operatorname{Pro}_{159}$, Ala $_{214}$, Pro $_{153}, \mathrm{Cys}_{154}, \mathrm{Gln}_{150}$ residues of Parkin with $-5.3 \mathrm{kcal} / \mathrm{mol}$ binding affinity and $\mathrm{Ki}=129.051 \mu \mathrm{M}$ (Table 3).

\section{Analysis of reactivity using DFT}

The DFT result exhibited that the 5 selected phytochemicals have high reactivity against the targeted protein. The energy gap values ranged from $0.115 \mathrm{kcal} / \mathrm{mol}$ to $0.160 \mathrm{kcal} / \mathrm{mol}$ and proved their high reactivity abilities. The values of $\mathrm{E}_{\mathrm{Lumo}}$ and $\mathrm{E}_{\text {номо }}$ were also low, exhibiting the fact that lower band energy gaps result in the high affinity of the inhibitors for the target proteins. Among these phytochemicals, Liquirtin showed the highest reactivity against the targeted protein, because the band energy exhibited was lowest among that of all the phytochemicals i.e. $0.115 \mathrm{kcal} / \mathrm{mol}$ (Table 4).

\section{Discussion}

Parkinson's disease (PD), a neurodegenerative disorder, named after the name of English physician James Parkinson who described it in work entitled "An essay on the shaking palsy" from 1817. It is a progressive loss of dopaminergic nigrostriatal neurons. First medical symptoms of PD seen after at least $60 \%-80 \%$ of nigrostriatal dopaminergic neurons have become dysfunctional. The most common clinical features include resting tremble, inflexibility, bradykinesia and postural shakiness [34].

There are many known causes reported for PD but the formation of Lewy bodies and loss of neuron function due to mutations in the Parkin gene are the key cause that contributes 60 to $70 \%$ of cases [35]. Parkin, an E3 ubiquitin ligase concerned in Parkinson's disease, triggers degradation

Table 4: Band energy gaps of selected phytochemicals.

Phytochemicals LUMO (kcal/mol) HOMO (kcal/mol) Band Energy Gap (kcal/mol)

\begin{tabular}{|c|c|c|c|}
\hline Liquirtin & -0.290 & -0.405 & 0.115 \\
\hline Shinflavanone & -0.192 & -0.312 & 0.120 \\
\hline Glabrone & -0.300 & -0.444 & 0.144 \\
\hline GlycyrdioneB & -0.128 & -0.285 & 0.157 \\
\hline IsoangustoneA & -0.136 & -0.296 & 0.160 \\
\hline
\end{tabular}

of mal-functional mitochondria by autophagy. By proteomic and cellular tactics, it has been shown that upon translocation to mitochondria, Parkin activates the UPS for pervasive degradation of outer membrane proteins. Because of some genetic and environmental factors if any mutation occurs in Parkin then the whole process of autophagy and ubiquitination disturbed [36-38].

In the existing PD genetics nomenclature, 18 specific chromosomal regions are named as PARK, and 18 PD-related genetic loci (PARK1-18) were recognized in chronological order [39]. So the Mutations labelled for these familial forms of PD, include autosomal dominant mutations of SNCA (PARK1, PARK4) [40], UCHL1 (PARK5), LRRK2 (PARK8) [41], HTRA2 (PARK13)[42] or autosomal recessive mutations of Parkin (PARK2) [43], PINK1 (PARK6) [44], DJ-1 (PARK7) [45] and ATP13A2 (PARK9) [46]. These are the genes (PARK) that are linked with PD.

Bioactive phytochemicals or bio-nutrients are found in medicinal plants in huge amount. Throughout the past 2-3 decades, studies have shown that these phytochemicals have a crucial role in curbing with chronic diseases like cancer, diabetes and coronary heart disease [47]. Also, phytomedicine has long been used to cure neural diseases like mental disorders, including neurodegenerative diseases such as $\mathrm{AD}, \mathrm{PD}$ and many other memory-related disorders. Currently, increasing evidence directs that neuroglia derived chronic inflammatory responses play a compulsive role in the central nervous system. Phytomedicines that have anti-inflammatory properties and its constituents are being ascertained to be a potent neuroprotector against various brain disorders $[48,49]$.

There are few ADMET properties that are to be passed by a compound to act like a drug. One of them is BBB permeability. BBB has become the bottleneck in brain drug development as it is the single most important factor limiting the future growth of neurotherapeutics [50]. Especially in case of neural disorders, it is a most complex phenomenon that either a drug can cross BBB or not as it is reported in the previous literature that a drug can be more effective if it would not cross that barrier [51]. Conversely, in many brain pathologies like AD, it is necessary for a drug to be BBB permeant to enhance efficiency $[52,53]$. So from the neuropathic literature it is cleared that a drug must be BBB permeant in case of cognitive disorders [54]. 
Other properties include Lipinski's rule of five which determine either a compound can be orally used or not. This rule deals with the suitable number of hydrogen bonds of donor and acceptor, molecular weight and $\log \mathrm{P}$ of the compound to assure its drug likeliness [55]. Furthermore, it was seen that the phytochemicals having property of BBB permeability also showed high GI absorption which is linked with epithelial cells. Additionally, the phytochemicals showing optimum (high and moderate) solubility were only selected for analysis, which is known as an effective parameter in the drug discovery process [56].

Computer-aided protocols of drug discovery [57-60] have proven to be very efficient and effective, as reported in various previous studies [61-65]. Opting these protocols, presently, the five phytochemicals which were screened out for further in vitro and in vivo analysis have been reported in many studies for their pharmaceutical properties [66-68]. Interestingly, five out of five phytochemicals are from the same plant G. glabra (Liquorice), having neuroprotective potential. Hence, the present in silico study was centred on phytochemicals from very effective and potent medicinal herb- G. glabra [69].

These five phytochemicals are; Liquirtin, Shinflavanone, Glabrone, GlycyrdioneB and IsoangustoneA. Liquirtin and Shinflavanone are flavonoids, extracted from the dried roots of the plant [70]. Liquiritin has been reported previously that it is being used as an active compound which inhibits a capsaicin-induced cough [71]. It has been reported that flavonoids of this plant-like Shinflavanone have an exceptionally strong antioxidant activity which was found to be over 100 times stronger than that of antioxidant activity of vitamin E [72]. Isoflavonoids such as GlycyrdioneB, Glabrone and their derivatives are found to be involved in the in vivo inhibition of Mycobacterium smegmatis and Candida albicans [73]. Isoangustone $A$, an active phytochemical of Liquorice induced the programmed cell death of DU145 cells.Overall the biotic effects of IsoangustoneA have not, thus far, been studied extensively and is only reported to exert antibacterial effects on methicillin-resistant Staphylococcus aureus [73].

To check the efficacy of present findings (phytochemicals), experimental inhibitors which are reported in previous studies were also docked and results were compared. Total 15 such compounds were collected from different studies and their structures were retrieved for further process. All these compounds were docked against the targeted protein, Parkin, and their binding affinities, $\mathrm{K}_{\mathrm{i}}$ constants, and interactions were analysed. ADMET analysis of these compounds was also performed.

By comparing the results of both the present and previously reported studies it was cleared that the novel inhibitors evaluated in this study are far more efficient and potent than the previous one. The binding energies of novel inhibitors are greater than those of experimental ones i.e., $-5.5 \mathrm{kcal} / \mathrm{mol}$ of Liquirtin with $\mathrm{K}_{\mathrm{i}}$ value of $92.044 \mu \mathrm{M}$ while the highest binding affinity from experimental inhibitors was $-5.2 \mathrm{kcal} / \mathrm{mol}$ and $\mathrm{Ki}=152.807 \mu \mathrm{M}$. Going towards ADMET parameters it was found that all the five novel inhibitors are BBB permeant, have High
GI absorption, optimum solubility and o violations of Lipinski's rule. While ADMET results of experimental inhibitors showed that just five out of fifteen are BBB permeant, four of them violates Lipinski's rule (CoQ10, Creatine, Mavoglurant and MG132), One of them (Creatine) have very low GI absorption while CoQ10 and MG132 have poor solubility (Table 1).

\section{Conclusion}

This computational analysis was carried out to evaluate the inhibitory potential of phytochemicals from different plants against Parkin. The aim was to discover a potent inhibitor as candidate drugs against Parkinson's disease as Parkin is the key source of this neural pathology. In this study, five phytochemicals named as Liquirtin, Shinflavanone, Glabrone, GlycyrdioneB and IsoangustoneA from plant Glycyrrhiza glabra, were selected after screening on the basis of Molecular docking, ADMET analysis and DFT calculations. Another important factor of this study was a comparison with previously reported experimental inhibitors. The results of this study revealed 5 novel inhibitors with binding affinity $>-5.2 \mathrm{kcal} / \mathrm{mol}$ and satisfactory ADMET profiles (after passing set criteria). However, these phytochemicals should be further assessed by in vivo and in vitro analysis for the development of a potent phyto-drug against Parkinson' disease.

\section{References}

1. Martin I, Dawson VL, Dawson TM (2011) Recent advances in the genetics of Parkinson's disease. Annu Rev Genomics Hum Genet 12: 301-325. Link: https://bit.ly/3fb6Ldb

2. Lücking CB, et al. (2000) French Parkinson's Disease Genetics Study Group European Consortium on Genetic Susceptibility in Parkinson's Disease Association between early-onset Parkinson's disease and mutations in the parkin gene. N Engl J Med 342:1560-1567.

3. Exner N, Lutz AK, Haass C, Winklhofer KF (2012) Mitochondrial dysfunction in Parkinson's disease: molecular mechanisms and pathophysiological consequences. EMBO J 31: 3038-3062. Link: https://bit.ly/3ffzjlM

4. Henchcliffe C, Beal MF (2008) Mitochondrial biology and oxidative stress in Parkinson disease pathogenesis. Nat Clin Pract Neurol 4: 600-609. Link: https://bit.ly/2YnBSLR

5. Abou-Sleiman PM, Muqit MM, Wood NW (2006) Expanding insights of mitochondrial dysfunction in Parkinson's disease. Nat Rev Neurosci 7: 207-219. Link: https://bit.ly/2XONMiY

6. Mayeux R, Denaro J, Hemenegildo N, Marder K, Tang MX, et al. (1992) A population based investigation of Parkinson's disease with and without dementia. Relationship to age and gender. Arch Neurol 49: 492-497. Link: https://bit.ly/2AWKYr6

7. Shimura H, Hattori N, Kubo SI, Mizuno Y, Asakawa S, et al. (2000) Familial Parkinson disease gene product, parkin, is a ubiquitin-protein ligase. Nat Genet 25: 302-305. Link: https://bit.ly/2XOW1vp

8. Walden H, Martinez-Torres RJ (2012) Regulation of Parkin E3 ubiquitin ligase activity. Cell Mol Life Sci 69: 3053-3067. Link: https://bit.ly/37h6HWO

9. Wauer T, Simicek M, Schubert A, Komander D (2015) Mechanism of phosphoubiquitin- induced PARKIN activation. Nature 524: 370-374. Link: https://bit.ly/37iaCCy

10. Ciechanover A, Brundin P (2003) The ubiquitin proteasome system in neurodegenerative diseases: sometimes the chicken, sometimes the egg. 40: 427446. Link: https://bit.ly/30wl72U

Citation: Arif N, Subhani A, Hussain W, Rasool N (2020) RComputer-aided Analysis of Selective Phytochemicals as Potent Inhibitors of Parkin: Major Biological Target of 
11. Narendra D, Tanaka A, Suen DF, Youle RJ (2008) Parkin is recruited selectively to impaired mitochondria and promotes their autophagy. J Cell Biol 183: 795-803. Link: https://bit.ly/30t1Y2F

12. Geisler S, Holmstrom KM, Skujat D, Fiesel FC, Rothfuss OC, et al. (2010) PINK1/ Parkin-mediated mitophagy is dependent on VDAC1 and p62/SQSTM1. Nat Cell Biol 12: 119-131. Link: https://bit.ly/3cQiTPo

13. Lee JY, Nagano Y, Taylor JP, Lim KL, Yao TP (2010) Disease-causing mutations in parkin impair mitochondrial ubiquitination, aggregation, and HDAC6-dependent mitophagy. J Cell Biol 189: 671-679. Link: https://bit.ly/2MNxeBG

14. Ding WX, Ni HM, Li M, Liao Y, Chen X, et al. (2010) Nix is critical to two distinct phases of mitophagy: reactive oxygen species (ROS)-mediated autophagy induction and Parkin-ubiqutin-p62-mediated mitochondria priming. J Biol Chem 285: 27879 27890. Link: https://bit.ly/3cPXFkz

15. Chung KKK, Thomas B, Li X, Pletnikova O, Troncoso JC, et al. (2008) S-nitrosylation of parkin regulates ubiquitination and compromises parkin's protective function. Science 304: 1328-1331. Link: https://bit.ly/3hhcYpM

16. LaVoie MJ, Ostaszewski BL, Weihofen A, Schlossmacher MG, Selkoe DJ (2005) Dopamine covalently modifies and functionally inactivates parkin. Nat Med 211: 1214-1221. Link: https://bit.ly/2MlwkGB

17. Dawson TM, Dawson VL (2014) Parkin plays a role in sporadic Parkinson's disease. Neurodegener Dis 13: 69-71. Link: https://bit.ly/37iBN01

18. Goldberg MS, Fleming SM, Palacino JJ, Cepeda C, Lam HA, et al. (2003) Parkin deficient mice exhibit nigrostriatal deficits but not loss of dopaminergic neurons. J Biol Chem 278: 43628-43635. Link: https://bit.ly/2UuWoZM

19. Perez FA, Palmiter RD (2005) Parkin-deficient mice are not a robust model of parkinsonism. Proc Natl Acad Sci USA 102: 2174-2179. Link: https://bit.ly/3hgenNC

20. Williamson EM (2001) Synergy and other interactions in phytomedicines Phytomedicine 8: 401-409. Link: https://bit.ly/3hd4pwr

21. Briskin DP (2000) Medicinal plants and phytomedicines. Linking plant biochemistry and physiology to human health. Plant Physiol 124: 507-514. Link: https://bit ly/2UsRb4|

22. Hasler CM, Blumberg JB (1999) Symposium on Phytochemicals: Biochemistry and Physiology. J Nutrition 129: 756S-757S. Link: https://bit.ly/2AbTx1f

23. Wadood A, Ahmed N, Shah L, Ahmad A, Hassan H, et al. (2013) In-silico drug design: An approach which revolutionarised the drug discovery process. Drug Des Devel Ther 1: 3. Link: https://bit.ly/2UuU9pn

24. Briskin DP (2000) Medicinal plants and phytomedicines. Linking plant biochemistry and physiology to human health. Plant Physiol 124: 507-514. Link: https://bit. Iy/2MKI9Mj

25. Biological Macromolecular Structures Enabling Breakthroughs in Research and Education.

26. Lee SK, Park SH, Lee IH, No KT (2007) PreAD-MET Ver. v2.0. Seoul, Korea: BMDRC.

27. Seal A, Aykkal R, Babu RO, Ghosh M (2011) Docking study of HIV-1 reverse transcriptase with phytochemicals. Bioinformation 5: 430-439. Link: https://bit. ly/2UuVjkG

28. Trott O, Olson AJ (2010) AutoDock Vina: Improving the speed and accuracy of docking with a new scoring function, efficient optimization, and multithreading. $J$ Comput Chem 31: 455-61. Link: https://bit.ly/2XQ5wdR

29. Morris GM, Huey R, Olson AJ (2008) Using auto Dock for ligand-receptor docking. Curr Protoc Bioinformatics. Link: https://bit.ly/2AQTPdL

30. Morris GM, Huey R, Olson AJ (2008) Using autoDock for ligand-receptor docking. Curr Protoc Bioinformatics. Link: https://bit.ly/2AQTPdL

31. Trott O, Olson AJ (2010) AutoDock Vina: Improving the speed and accuracy of docking with a new scoring function, efficient optimization, and multithreading. J Comput Chem 31: 455-461. Link: https://bit.ly/2XQ5wdR

32. Gill PM, Johnson BG, Pople JA, Frisch MJ (1992) The performance of the Becke-Lee-
Yang-Parr (B-LYP) density functional theory with various basis sets. Chem Phys Lett 197: 499-505. Link: https://bit.ly/2Ys4XWO

33. Neese F (2012) The ORCA program system. Wiley Interdisciplinary Reviews: Rev Comput Mol Sci 2: 73-81. Link: https://bit.ly/2Usy0s4

34. Bernheimer H, Birkmayer W, Hornykiewicz Jellinger K, Seitelberger F (1973) Brain dopamine and the syndromes of Parkinson and Huntington. J Neurol Sci 20:415-55. Link: htps://bit.ly/30uu51K

35. Lücking $C B$, et al. French Parkinson's Disease Genetics Study Group. European Consortium. on Genetic Susceptibility in Parkinson's Disease Association between early-onset Parkinson's disease and mutations in the parkin gene. N Engl J Med 2000 342: 1560-1567.

36. Shimura H, Hattori N, Kubo S, Mizuno Y, Asakawa S, et al. (2000) Familial Parkinson disease gene product, parkin, is a ubiquitin-protein ligase. Nat Genet 25: 302-305. Link: https://bit.ly/3dPM46D

37. Lee JY, Nagano Y, Taylor JP, Lim KL , Yao TP (2010) Disease-causing mutations in parkin impair mitochondrial ubiquitination, aggregation, and HDAC6-dependent mitophagy. J Cell Biol 189: 671-679. Link: https://bit.ly/3fccPIW

38. Ciechanover A , Brundin P (2003) The ubiquitin proteasome system in neurodegenerative diseases: sometimes the chicken, sometimes the egg. Neuron 40: 427-446. Link: https://bit.ly/30sjWm0

39. Klein C, Westenberger A (2012) A Genetics of Parkinson's disease. Cold Spring Harb Perspect Med 2: a008888. Link: https://bit.ly/2YeD1oU

40. Polymeropoulos MH, Lavedan C, Leroy E, Ide SE, Dehejia A, et al. (1997) Mutation in the alpha-synuclein gene identified in families with Parkinson's disease. Science276: 2045-2047. Link: https://bit.ly/2AW47tf

41. Funayama M, Hasegawa K, Kowa H, Saito M, Tsuji S, et al. (2002) new locus for Parkinson's disease (PARK8) maps to chromosome 12p11.2-q13.1. Ann Neurol 51 296-301. Link: https://bit.ly/3cOSS34

42. Martins LM, Morrison A, Klupsch K, Fedele V, Moisoi N, et al. (2004) Neuroprotective role of the Reaper-related serine protease $\mathrm{HtrA} 2 / \mathrm{Omi}$ revealed by targeted deletion in mice. Mol Cell Biol24: 9848-9862. Link: https://bit.ly/2AoXf7z

43. Mizuno Y, Hattori N, Kubo S, Sato S, Nishioka K, et al. (2008) Progress in the pathogenesis and genetics of Parkinson's disease. Philos Trans R Soc Lond B Biol Sci 363: 2215-2227.Link: https://bit.ly/2UpTIST

44. Hatano Y, Li Y, Sato K, Asakawa S, Yamamura Y, et al. (2004) Novel PINK1 mutation in early-onset parkinsonism. Ann Neurol56: 424-427.Link: https://bit.ly/2AW301z

45. Bonifati V, Rizzu P, Squitieri F, Krieger E, Vanacore N, et al. (2003) DJ-1( PARK7), a novel gene for autosomal recessive, early onset parkinsonism. Neurol Sci 24: 159160.Link: https://bit.ly/3hitrue

46. Ramirez A, Heimbach A, Gründemann J, Stiller B, Hampshire D, et al. (2006) Hereditary parkinsonism with dementia is caused by mutations in ATP13A2, encoding a lysosomal type 5 P-type ATPase. Nat Genet 38: 1184-1191. Link: https:// bit.ly/2BUqX4X

47. Hasler CM, Blumberg JB(1999) Symposium on Phytochemicals: Biochemistry and Physiology. J Nutr 129: 756S-757S. Link: https://bit.ly/3fdNurU

48. Commenges D, Scotet V, Renaud S, Jacqmin-Gadda $H$,Barberger Gateau $P$, et al. (2000) Intake of $\mathrm{fl}$ avonoids and risk of dementia. Eur J Epidemiol 6: 357-363. Link: https://bit.ly/3haELs6

49. Pueyo IU, Calvo MI (2009) Phytochemical Study and Evaluation of Antioxidant Neuroprotective,Acetylcholinesterase Inhibitor Activities of Galeopsis ladanum extracts. Pharmacognosy Mag 5: 287-90. Link: https://bit.ly/2MO639P

50. Pardridge WM (2001) Brain drug targeting: the future of brain drug development Cambridge, UK: Cambridge University Press. Link: https://bit.ly/2BQINXV

51. Tran N (2011) Blood-brain barrier. In: Kreutzer Jeffrey, DeLuca John, Caplan Bruce, editors. Encyclopedia of Clinical Neuropsychology,l edn. New York: Springer 2011 p. 426.

Citation: Arif N, Subhani A, Hussain W, Rasool N (2020) RComputer-aided Analysis of Selective Phytochemicals as Potent Inhibitors of Parkin: Major Biological Target of Parkinson's disease. Glob J Biotechnol Biomater Sci 6(1): 013-023. DOI: https://dx.doi.org/10.17352/gjbbs.000013 
52. Rosenberg GA, Yang Y (2007) Vasogenic Edema Due to Tight Junction Disruption by Matrix Metalloproteinases in Cerebral Ischemia.Neurosurg Focus. 22: E4. Link: https://bit.ly/2Uwa6fc

53. Gasche Y, Soccal PM, Kanemitsu M, Copin JC (2006) Matrix Metalloproteinases and Diseases of the Central Nervous System With a Special Emphasis on Ischemic Brain. Front Biosci. 11: 1289-301. Link: https://bit.ly/3cPTGED

54. Lipinski CA, Lombardo F, Dominy BW, Feeney PJ (1997) Experimental and computational approaches to estimate solubility and permeability in drug discovery and development settings. Adv Drug Deliv Rev 23: 3-25. Link: https://bit.ly/30pMgpf

55. Kawabata Y, Wada K, Nakatani M, Yamada S, Onoue S (2011) Formulation design for poorly water-soluble drugs based on biopharmaceutics classification system: Basic approaches and practical applications. Int J Pharm420: 1-10. Link: https://bit.ly/3heluov

56. Akhtar A, Amir A, Hussain W, Ghaffar A, Rasool N (2019) In Silico Computations Of Selective Phytochemicals As Potential Inhibitors Against Major Biological Targets Of Diabetes Mellitus. Curr Comput Aided Drug Des 15. Link: https://bit.ly/2Ae3DyJ

57. Akhtar A, Hussain W, Rasool N (2019) Probing the Pharmacological Binding Properties, and Reactivity of Selective Phytochemicals as Potential HIV-1 protease Inhibitors. Universitas Scientiarum 24: 441-464. Link: https://bit.ly/3hlebgb

58. Amjad, H, Hussain, W, Rasool N (2018) Molecular Simulation Investigation of Prolyl Oligopeptidase from Pyrobaculum Calidifontis and In Silico Docking With Substrates and Inhibitors. Open Access Journal Of Biomedical Engineering And Biosciences 2: 185-194. Link: https://bit.ly/2YjSowp

59. Arif N, Subhani A, Hussain W, Rasool N (2019) In Silico Inhibition of BACE-1 by Selective Phytochemicals as Novel Potential Inhibitors: Molecular Docking and DFT Studies. Current Drug Discovery Technologies, E-pub Ahead of Print. Link: https://bit.ly/2XMkjWS

60. Hussain W, Ali M, Sohail Afzal M, Rasool N (2018) Penta-1,4-Diene-3-One Oxime Derivatives Strongly Inhibit the Replicase Domain of Tobacco Mosaic Virus: Elucidation Through Molecular Docking and Density Functional Theory Mechanistic Computations. Journal of Antivirals \& Antiretrovirals 10. Link: https://bit.ly/2YpAbgY

61. Hussain W, Qaddir I, Mahmood S, Rasool N (2018) In silico targeting of non-structura $4 \mathrm{~B}$ protein from dengue virus 4 with spiropyrazolopyridone: study of molecular dynamics simulation, ADMET and virtual screening. Virus Disease 29: 147-156. Link: https://bit.ly/2X068jU

62. Qaddir I, Rasool N, Hussain W, Mahmood S (2017) Computer-aided analysis of phytochemicals as potential dengue virus inhibitors based on molecular docking, ADMET and DFT studies. J Vector Borne Dis54: 255-262. Link: https://bit.ly/2Yktyg7
63. Rasool N, Ashraf A, Waseem M, Hussain W, Mahmood S (2018) Computational exploration of antiviral activity of phytochemicals against NS2B/NS3 proteases from dengue virus. Turkish Journal of Biochemistry. Link: https://bit.ly/2AURsGY

64. Rasool N, Hussain W (2019) Three Major Phosphoacceptor Sites in HIV-1 Capsid Protein Enhances its Structural Stability and Resistance against Inhibitor: Explication through Molecular Dynamics Simulation, Molecular Docking and DFT Analysis. Comb Chem High Throughput Screen. Link: https://bit.ly/3fc82AY

65. Rasool N, Hussain W, Mahmood S (2017) Prediction of Protein Solubility using Primary Structure Compositional Features: A Machine Learning Perspective. Journal of Proteomics \& Bioinformatics 10: 324-328. Link: https://bit.ly/30FbQH1

66. Rasool N, Husssain W, Khan YD (2019) Revelation of enzyme activity of mutant pyrazinamidases from Mycobacterium tuberculosis upon binding with various metals using quantum mechanical approach. Computational biology and chemistry 83: 107-108. Link: https://bit.ly/2ULpCEf

67. Rasool N, Jalal A, Amjad A, Hussain W (2018) Probing the Pharmacological Parameters, Molecular Docking and Quantum Computations of Plant Derived Compounds Exhibiting Strong Inhibitory Potential Against NS5 from Zika Virus. Brazilian Archives of Biology and Technology 61. Link: https://bit.ly/2XMRqdc

68. Kataria R, Hemraj, Singh G, Gupta A, Jalhan S, et al. (2013) Pharmacological activities on Glycyrrhiza glabra-a review. Asian J Pharm Clin Res 6: 5-7. Link: https://bit.ly/2Yj7anm

69. The wealth of India. (2005) A Dictionary of Indian Raw Materials and Industrial Products, First supplement series, National Institute of Sciences Communication and Information Resources, 3, CSIR, New Delhi, D-1, 195-198.

70. Kamei J, Nakamura R, Ichiki H, Kubo M (2003) Antitussive principles of Glycyrrhiza radix, a main component of Kampo preparations Bakumondo-to (Mai-mendongtang). Eur J Pharmacol 469: 159-163. Link: https://bit.ly/3cNn52s

71. Ju HS, Li XJ, Zhao BL, Han ZW, Xin WJ (1989) Effects of Glycyrrhiza Flavonoids on lipid peroxidation and active oxygen radicals. Yao Xue Xue Bao 24: 807-812. Link: https://bit.ly/2Uw7Wfx

72. Alonso J (2003) Tratado de Fitofármacos y Nutracéuticos.www.fitoterapia.net. Barcelona: Corpus, J Pharm 69:159-163.

73. Hatano T, Shintani Y, Aga Y, Shiota S, Tsuchiya T, et al. (2000) Phenolic constituents of licorice. VIII. Structures of glicophenone and glicoisoflavanone, and effects of licorice phenolics on methicillin-resistant Staphylococcus aureus. Chem Pharm Bull 48: 1286-1292. Link: https://bit.ly/3fb5tyU

\section{Discover a bigger Impact and Visibility of your article publication with}

\section{Peertechz Publications}

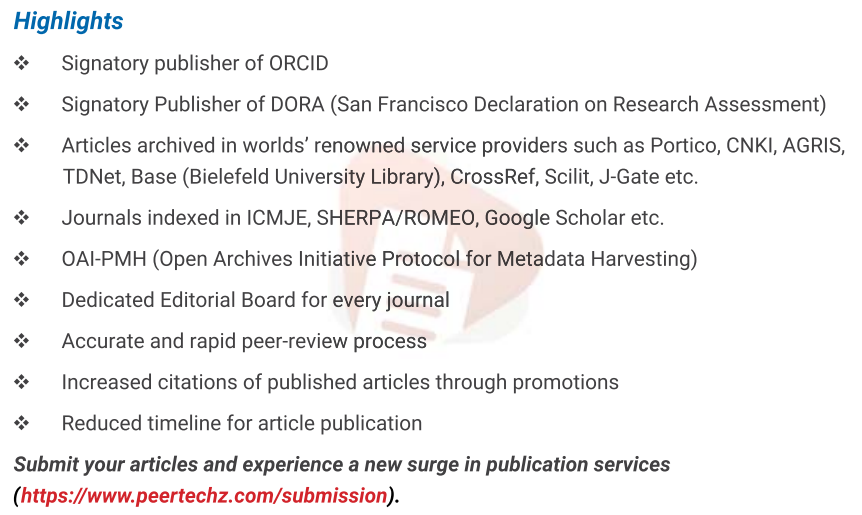

Peertechz journals wishes everlasting success in your every endeavours.

Copyright: @ 2020 Arif N, et al. This is an open-access article distributed under the terms of the Creative Commons Attribution License, which permits unrestricted use, distribution and reproduction in any medium, provided the original author and source are credited.

Citation: Arif N, Subhani A, Hussain W, Rasool N (2020) RComputer-aided Analysis of Selective Phytochemicals as Potent Inhibitors of Parkin: Major Biological Target of Parkinson's disease. Glob J Biotechnol Biomater Sci 6(1): 013-023. DOI: https://dx.doi.org/10.17352/gjbbs.000013 